\title{
Alertness, Judgment, and the Antecedents of Entrepreneurship
}

Foss, Nicolai Juul; Klein, Peter G.

Document Version

Final published version

Publication date:

2010

License

CC BY-NC-ND

Citation for published version (APA):

Foss, N. J., \& Klein, P. G. (2010). Alertness, Judgment, and the Antecedents of Entrepreneurship. Center for Strategic Management and Globalization. SMG Working Paper No. 3/2010

Link to publication in CBS Research Portal

\section{General rights}

Copyright and moral rights for the publications made accessible in the public portal are retained by the authors and/or other copyright owners and it is a condition of accessing publications that users recognise and abide by the legal requirements associated with these rights.

Take down policy

If you believe that this document breaches copyright please contact us (research.lib@cbs.dk) providing details, and we will remove access to the work immediately and investigate your claim. 
Alertness, Judgment, and the Antecedents of Entrepreneurship

Nicolai J. Foss

Peter G. Klein

SMG WP 3/2010

March 29, 2010 
SMG Working Paper No. 3/2010

March 29, 2010

ISBN: 978-87-91815-56-0

Center for Strategic Management and Globalization Copenhagen Business School

Porcelænshaven 24

2000 Frederiksberg

Denmark

www.cbs.dk/smg 
ALERTNESS, JUDGMENT, AND THE ANTECEDENTS OF ENTREPRENEURSHIP

\author{
Nicolai J. Foss \\ Center for Strategic Management and Globalization \\ Copenhagen Business School \\ Porcelainshaven 24B; 2000 Frederiksberg; Denmark \\ njf.smg@,cbs.dk \\ and \\ Department of Strategy and Management \\ Norwegian School of Economics and Business Administration \\ Breiviksveien 40, N-5045 \\ Bergen; Norway \\ Peter G. Klein \\ Division of Applied Social Sciences \\ University of Missouri \\ pklein@missouri.edu \\ and \\ Department of Strategy and Management \\ Norwegian School of Economics and Business Administration \\ Breiviksveien 40, N-5045 \\ Bergen; Norway \\ Prepared for the Journal of Private Enterprise; March 26, 2010
}

\begin{abstract}
This paper offers a critical perspective on Israel Kirzner's basic analytical framework. Specifically, we characterize Kirzner's emphasis on processes of equilibration as a departure from the causal-realist price theory developed by Menger and his nineteenth- and twentieth-century followers. In this context, we contrast Kirzner's interpretation of entrepreneurship as discovery with a more realistic, and operationally meaningful, idea of entrepreneurship as action. Finally, we discuss an inconsistency in Kirzner's treatment of the antecedents of entrepreneurial behavior.
\end{abstract}

Acknowledgments: We thank Dan Klein and Joe Salerno for helpful conversations and Per Bylund and Claus Vistesen for research assistance. The usual caveat applies.

Keywords: Austrian economics, entrepreneurship, discovery, judgment, causal-realism

JEL Codes: B53, D01, D83 


\section{INTRODUCTION}

Israel Kirzner's concept of entrepreneurship as alertness to profit opportunities is conventionally seen as one of the seminal contributions to modern entrepreneurship theory along with those of Schumpeter (1911) and Knight (1921). The distinction between "Schumpeterian" and "Kirznerian" entrepreneurs has become standard in the literature (although Kirzner (2009) himself contests the distinction). Among Austrian economists, Kirzner's understanding of the market as "an entrepreneurially driven process" (Kirzner, 1997, p.67) and a "process of mutual discovery" (Kirzner, 1997, p.71) is a dominant perspective on production, exchange, and welfare. ${ }^{1}$

More recently, Kirzner's concept of entrepreneurship has also become hugely influential in management research on entrepreneurship (e.g., Shane and Venkataraman, 2000; Shane, 2003), where the "opportunity identification" literature seeks to build a positive research program by operationalizing alertness and identifying its cognitive and motivational antecedents. The aim is to understand what drives opportunity discovery on the level of individual entrepreneurs (Cooper et al., 1995; Gaglio and Katz, 2001) — a research program in many ways inconsistent with Kirzner's own understanding of the implications of his approach (Klein, 2008b; Kirzner, 2009).

Kirzner's research program is under discussion elsewhere in this issue, but mainly from perspectives that accept the basic Kirznerian understanding of the nature of the entrepreneur and the market, namely that entrepreneurship is best conceived as the discovery of hitherto unknown profit opportunities, and that entrepreneurial action tends to move market prices and quantities toward long-run equilibrium values. We offer here a different, perhaps more fundamental critique of Kirzner, one that questions the basic concept of entrepreneurship as alertness or discovery. We contrast Kirzner's emphasis on equilibration and the role of the "pure

\footnotetext{
${ }^{1}$ Kirzner's work has given rise to much critical discussion since its original statement in Kirzner's Competition and Entrepreneurship (1973), mainly (but not exclusively, e.g., Demsetz, 1983) among Austrian economists (Rothbard, 1974; High, 1982; Salerno, 1993, 2008).
} 
entrepreneur" in explaining equilibrating tendencies, with the causal-realist price-theory tradition from the Scholastics to Cantillon to Menger to Wicksteed, Fetter, and Davenport to Mises and his students. In the latter tradition, the aim is to explain actual, real-world, short-term market prices and not hypothetical processes of equilibration moving those prices toward longer-run equilibrium values Klein (2008a). In this tradition, as we interpret it, there is little need to invoke Kirznerian discovery. Relatedly, we contrast the discovery approach with an alternative interpretation of entrepreneurship that we associate with Cantillon (1730), Knight (1921), and Mises (1949), an approach in which entrepreneurship is interpreted not as alertness or discovery, but as action under uncertainty. Importantly, the Kirznerian notion of alertness does not presuppose uncertainty, and it differs from the concept of action in having no opportunity cost. In this context, we criticize Kirzner's denial that the entrepreneur must own capital.

Finally, we discuss an inconsistency in Kirzner's treatment of the antecedents of entrepreneurial discovery. Ideal types can be more or less anonymous Schutz (1932), and Kirzner's pure entrepreneur is particularly anonymous, more so than Mises's property-owning capitalist-entrepreneur. While the capitalist-entrepreneur, who is not merely a "discoverer" but a buyer and seller, acts within and is affected by a particular institutional setting, Kirzner's discoverer-entrepreneur exists outside any particular institutional environment. Indeed, Kirzner treats discovery as an explanatory primary, holding that personal, psychological, demographic, and similar characteristics cannot be invoked to explain discovery. And yet, at the same time, he has consistently argued that public policies inhibit entrepreneurial discovery (e.g., Kirzner, 1984), based on the notion that public policies block profit opportunities.

\section{THE MARKET VERSUS THE “MARKET PROCESS”}

In previous works we have distinguished Kirzner's understanding of entrepreneurship as discovery from the "judgment" approach that we associate with Mises and Frank Knight, and that we have developed in our own work (Foss and Klein, 2005; Foss, Foss, Klein, and Klein, 2007; Foss, Foss, and Klein, 2007; Klein, 2008b). Judgment refers primarily to business decision 
making when the range of possible future outcomes, let alone the likelihood of individual outcomes, is generally unknown (what Knight (1921) terms uncertainty, rather than probabilistic risk). Knight introduces judgment to link profit and the firm to uncertainty. Entrepreneurship represents judgment that cannot be assessed in terms of its marginal product and which cannot, accordingly, be paid a wage. ${ }^{2}$ This is because entrepreneurship is judgment in relation to the most uncertain events, such as starting a new firm, defining a new market, and the like. In other words, there is no market for the judgment that entrepreneurs rely on and, therefore, exercising judgment requires the person with judgment to purchase and organize factors of production-in other words, to start a firm. Judgment thus implies asset ownership, for judgmental decision making is ultimately decision making about the employment of resources.

The judgment approach fits, broadly, within the price-theoretic tradition of the Austrian school, what Klein (2008a) terms "mundane Austrian economics." This tradition, sometimes called "causal-realist” analysis following Menger's emphasis on causal explanation and a focus on real-world, day-to-day prices, emerged in the early twentieth century, but was largely supplanted by the Marshallian-Walrasian synthesis that dominated the economics profession after World War II (Salerno, 1993, 2002). Beginning with Hayek’s work on tacit knowledge (Hayek, 1937, 1945) and the competitive process (Hayek, 1948, 1968), Austrians began challenging the neoclassical assumption that prices can be assumed to equal their "equilibrium" values Machovec (1995). One interpretation of Kirzner's theory of entrepreneurship is that it provides an equilibration process that justifies the welfare conclusions of "standard" economics (namely, that markets are efficient means of allocating scarce resources). ${ }^{3}$ However, as Klein

\footnotetext{
${ }^{2}$ Compare Knight (1921, p.311): "The receipt of profit in a particular case may be argued to be the result of superior judgment. But it is judgment of judgment, especially one's own judgment, and in an individual case there is no way of telling good judgment from good luck and a succession of cases sufficient to evaluate the judgment or determine its probable value transforms the profit into a wage. . . . If . . capacities were known, the compensation for exercising them can be competitively imputed and is a wage; only, in so far as they are unknown or known only to the possessor himself, do they give rise to a profit."

${ }^{3}$ Kirzner's approach, as Boettke and Prychitko (1994, p.3) describes it, "provided the disequilibrium foundations of equilibrium economics that were required to complete the neoclassical project of explicating the operating principles of the price system." Adds Boettke (2005): "Why is all this important? Well as Franklin Fischer pointed out in his very important book The Disequilibrium Foundations of Equilibrium Economics (1983) that unless we have good
} 
(2008a) argues, causal-realist analysis is not concerned with long-run Marshallian or Walrasian equilibrium prices, but with actual, empirical, market prices, those occurring in what Mises calls the "plain state of rest." In this understanding of the market, the existence or non-existence of equilibrating tendencies - the issue that divided "Kirznerians" and "Lachmannians," and dominated much of the Austrian discussion in the 1980s - is relatively unimportant. For Mises, the critical "market process" is not the convergence to equilibrium, but rather the selection mechanism in which unsuccessful entrepreneurs - those who systematically overbid for factors, relative to eventual consumer demands - are eliminated from the market Mises (1951). It is this process that ensures that real-world, day-to-day prices are as "efficient" as they can be-in other words, that consumer sovereignty obtains at all times on the market. In Mises's system, neither consumer-goods nor factor prices “converge," in real time, to efficient, long-run equilibrium values, because the adjustment processes set in motion by profit-seeking entrepreneurs are frustrated, moment-by-moment, by exogenous changes in consumer preferences, technological knowledge, resource availabilities, and so on. ${ }^{4}$ The efficiency of the market, for Mises, results simply from the fact that prices are determined by the voluntary interactions of buyers and sellers according to their preferences over marginal units of goods and services. ${ }^{5}$

reasons to believe in the systemic tendency toward equilibrium we have no justification at all in upholding the welfare properties of equilibrium economics. In other words, without the sort of explanation that Kirzner provides the entire enterprise of neoclassical equilibrium is little more than a leap of faith."

${ }^{4}$ Nor do prices obtaining on real markets achieve a "coordination of plans," as final-goods prices may exceed or fall short of entrepreneurs' expectations (leading to profits and losses).

${ }^{5}$ In his article "Mises and His Understanding of the Capitalist System", Kirzner (1999) simultaneously accepts and dismisses Mises's welfare analysis of plain-state-of-rest prices. "Once we have understood the central position of the doctrine of consumer sovereignty in Mises' overall system, we can surely sense and appreciate the deep respect Mises felt for the actual market prices of productive resources. Certainly these prices are likely to be 'false' prices, in that they necessarily imperfectly anticipate the true future valuations of consumers for the various possible potential products (at the times when these products might conceivably be made available to consumers). Nonetheless, these prices, and the transactions in which they emerge, are wholly governed . . by the preferences of consumers" (p. 225). And yet, Kirzner writes, "Mises is clearly entirely aware that the market prices at any given date are almost certainly not the 'correct' prices" (i.e., they are not long-run equilibrium prices). For Mises, in Kirzner's interpretation, "[i]t is the market process, driven by the competition of profit-seeking entrepreneurs, that modifies those false prices and tends to ensure that they are replaced by prices more closely and 'truthfully' reflecting the underlying preferences of the consumers. What stimulates that process is the realization by entrepreneurs that the existing market-generated pattern of resource allocation is not the ideal one" (p. 216). If plainstate-of-rest prices are "wholly governed" by the preferences of consumers, then they are efficient, whether the market-process modifies them or not. 
As we interpret Mises, then, his entrepreneur plays a different role in the market system than that played by Kirzner's entrepreneur. Rather than an equilibrator, Mises's entrepreneur is a resource allocator. Mises begins with the marginal productivity theory of distribution developed by his Austrian predecessors. In the marginal productivity theory, laborers earn wages, landowners earn rents, and capitalists earn interest. ${ }^{6}$ Any excess (deficit) of a firm's realized receipts over these factor payments constitutes profit (loss). Profit and loss, therefore, are returns to entrepreneurship. In a hypothetical equilibrium without uncertainty (what Mises calls the evenly rotating economy), capitalists would still earn interest as a reward for lending, but there would be no profit or loss. Outside the evenly rotating economy, however, factors may be priced above or below these equilibrium values, and shrewd entrepreneurs can acquire factors for less than their discounted marginal revenue products, leading to profit. Less capable entrepreneurs will overpay for factors, or choose inefficient factor combinations, or produce the wrong products, among other errors, and earn losses. This understanding of the market is central to Mises's argument about the impossibility of economic calculation under socialism (i.e., a world without factor markets). ${ }^{7}$

For Kirzner, the main effect of entrepreneurship is to push real-world, disequilibrium prices toward their long-run, equilibrium values. He is not particularly interested in the determinants or welfare properties of day-to-day, plain-state-of-rest prices, but rather the presence or absence of equilibrating tendencies. But is entrepreneurship necessarily equilibrating markets within

\footnotetext{
${ }^{6}$ Following Fetter (1905), Rothbard $(1962,1978)$ characterizes all factor payments as rents, and emphasizes that in long-run equilibrium, only the "originary" factors land and labor earn net rents, while the gross rents accruing to capital goods are imputed back to the originary factors used to produce them.

${ }^{7}$ Entrepreneurs, in Mises's explanation, make their production plans based on the current prices of factors of production and the anticipated future prices of consumer goods. What Mises calls economic calculation is the comparison of these anticipated future receipts with present outlays, all expressed in common monetary units. Under socialism, the absence of factor markets and the consequent lack of factor prices render economic calculation-and hence rational economic planning - impossible. Mises's point is that a socialist economy may assign individuals to be workers, managers, technicians, inventors, and the like, but it cannot, by definition, have entrepreneurs, because there are no money profits and losses. Entrepreneurship, and not labor, management or technological expertise, is the crucial element of the market economy. As Mises puts it, directors of socialist enterprises may be allowed to "play market" - to make capital investment decisions as if they were allocating scarce capital across activities in an economizing way. But entrepreneurs cannot be asked to "play speculation and investment" (Mises, 1949, p. 705). Without entrepreneurship, a complex, dynamic economy cannot allocate resources to their highest-valued use.
} 
Kirzner's own analytical system? Several arguments have been advanced against Kirzner in the Austrian literature (Lachmann, 1986; Buchanan and Vanberg, 2008; Vaughn, 1992). First, if opportunities can be described as existing, objectively, then if entrepreneurs fail to discover all opportunities, equilibration does not take place (a possibility allowed for by Kirzner himself). ${ }^{8}$ Second, if by equilibrium Kirzner has in mind Hayek's sense of multi-period plan coordination, then Kirzner has introduced an intertemporal dimension that may wreak havoc with the whole notion of entrepreneurship as equilibrating. In parts of Kirzner's early work (e.g., Kirzner, 1978), the exercise of entrepreneurship does not seem to presuppose uncertainty. If entrepreneurship means overcoming sheer ignorance by the exercise of alertness, this is a logically correct inference. However, uncertainty is clearly a fundamental aspect of action Mises (1949), and it seems difficult to argue that a theory of entrepreneurship can meaningfully abstract from it. However, introducing uncertainty may destroy the basis for the claim that entrepreneurship is equilibrating in the sense of achieving Hayekian plan coordination. This, of course, formed the core of Lachmann's “equilibration skepticism” Lachmann (1986): Because of pervasive uncertainty, there is very little rational basis for entrepreneurs to form expectations of future consumer demands and resource scarcities, and such expectations are therefore more likely to be divergent than convergent.

Selgin (1987) argues that these debates misunderstand the nature of the equilibration process. Correctly understood, "equilibration" does not refer to coordination of plans as in Hayek (1937), mainstream stability theory, convergence to rational expectations equilibrium, and the like; it refers to entrepreneurial profits and losses. These are strictly subjective categories and have no objective basis outside the minds of entrepreneurs. Equilibration, in this sense, makes no reference to the state of knowledge of market participants and whether their plans are consistent. Indeed, Selgin (1987) dismisses the very notion of coordination in world in which profit opportunities cannot be thought of as "objectively existing", in which preferences have no existence apart from actions, etc. Mises, also, focused on action, not perception; in this sense, entrepreneurship is not

\footnotetext{
${ }^{8}$ See Alvarez and Barney (2007) and Klein (2008a) on the objectivity or subjectivity or entrepreneurial opportunities.
} 
about discovery in a hypothetical market construct, but the investment of resources under realworld conditions.

\section{THE ENTREPRENEUR AS CAPITAL OWNER}

Kirzner's ideal type of the "pure entrepreneur" is used to elucidate the coordinating function of entrepreneurship. While Clark and Mises introduced similar devices to emphasize selected aspects of entrepreneurship (Salerno, 2008; Klein and Foss, 2010), Kirzner sees his construct as capturing its very essence. Kirzner does not deny that business people, resource owners, financiers, traders, and the like exercise judgment, or that they possess boldness, creativity, and imagination, only that they need not exercise these functions to be alert to previously unknown profit opportunities. "My entrepreneurs were engaged in arbitrage, acting entrepreneurially even when they might not be seen as Schumpeterian 'creators.' . . In so emphasizing the difference between Schumpeter's theory of entrepreneurship and my own, I was motivated by my primary scientific objective. This was to understand the nature of the market process - even in its simplest conceivable contexts" (Kirzner, 2009, p.147).

In elucidating his conception of the entrepreneurial market process, Kirzner has consistently emphasized the highly abstract nature of his "metaphor" of the entrepreneur Kirzner (2009). ${ }^{9}$ In contrast, most contributors to the entrepreneurship literatures in management and economics have given more detail to the entrepreneurial function. The amount of detail differs, however, depending on the explanatory purpose. For example, the opportunity-discovery literature in management research is taken up with the antecedents of specific, individual entrepreneurs and as such takes a rather detailed view of the entrepreneur (e.g., Shane, 2003). The judgment approach described above is concerned with the more "functional" (Klein, 2008b) issue of understanding the market selection process in the context of the profit and loss mechanism, and

\footnotetext{
${ }^{9}$ Kirzner's use of the notion of "metaphor" to characterize his entrepreneur construct seems puzzling: At least in usual parlance, a "metaphor" is a figure of speech in which a term or concept is used as a reference to something that it does not literally denote so that a potentially illuminating similarity is revealed. Isn't Kirzner talking about realworld entrepreneurs? We return to this issue later.
} 
of understanding profit as a reward to entrepreneurship. In elucidating these functions, the judgment approach provides a somewhat richer view of the entrepreneur than the ghost-like Kirznerian pure entrepreneurs. Specifically, the judgment approach treats entrepreneurship as decision-making under uncertainty, implying asset ownership (Foss and Klein, 2005). It seeks to explain not only discovery, but action, focusing on what Salerno (2008) calls the "integral entrepreneur," combining abstract processes of imagination and creativity with action on real markets. It may therefore be claimed to occupy a middle ground between the opportunitydiscovery literature of recent management research and Kirzner's work on the pure entrepreneur.

Kirzner has consistently emphasized that his "contribution is simply an extension and deepening of insights articulated by my teacher, Ludwig von Mises” (Kirzner, 2009, p.146). Specifically, the key insight in Mises that Kirzner's work purportedly has sought to "expound and develop" (Kirzner, 2009, p.148) is the following one: "What makes profit emerge is the fact that the entrepreneur who judges the future prices of the products more correctly than other people do buy some or all of the factors of production at prices which, seen from the point of view of the future state of the market, are too low" (Mises, 1952, p.190). Kirzner argues that his notion of alertness (to price discrepancies) captures the essence of the Misesian view of entrepreneurship as captured in this quotation, and that, therefore, the simple model of the pure entrepreneur undertaken nearly-instantaneous arbitrage can be applied even to those situations where the discrepancies between the "future prices of the products" and the imputed prices of the "factors of production" involve very long time.

By contrast, the Knightian (and, we would argue, Misesian) entrepreneur who owns capital and bears uncertainty — acting in calendar time - may possess the characteristics of the Kirznerian entrepreneur (i.e., being alert to potential, imagined opportunities for gain) but in addition must also possess the special faculty of exercising judgment uncertainty and must be a 
capital owner (Foss and Klein, 2005; Foss, Foss, Klein and Klein, 2007). ${ }^{10}$ In contrast, Kirzner insists that the pure entrepreneur is a non-owner.. "An important point," Kirzner argues (1978, p. 47), "is that ownership and entrepreneurship are to be viewed as completely separate functions. Once we have adopted the convention of concentrating all elements of entrepreneurship into the hands of pure entrepreneurs, we have automatically excluded the asset owner from an entrepreneurial role. Purely entrepreneurial decisions are by definition reserved to decision-makers who own nothing at all." Thus, the entrepreneur is a pure decision maker, and nothing else. And yet, Kirzner's strict separation between the "discovery" and "ownership" functions of the entrepreneur raises some conceptual difficulties. As Rothbard (1985) noted, unless buying and selling are instantaneous, even arbitrageurs bear uncertainty, in that selling prices may change after goods and services are acquired for arbitrage. ${ }^{11}$

\section{ANTECEDENTS OF OPPORTUNITY DISCOVERY}

Alertness to opportunities, the discovery of specific opportunities, and action based on those discovered opportunities are typically portrayed as discrete phases of market behavior. These phases could conceivably be separated by long stretches of time, and could have widely different antecedents or determinants. The applied entrepreneurship literature typically distinguishes between opportunity recognition (discovery) and opportunity exploitation (investment, firm formation, etc.), and has devoted considerable attention to cognitive and learning processes that might lead to discovery (Short, Ketchen, Shook, and Ireland, 2010, p. 55-56).

\footnotetext{
${ }^{10}$ Klein (2008b) emphasizes that under uncertainty, profit opportunities never exist, objectively, that they are neither "discovered" nor "created," but rather imagined, in the mind of the actor.

${ }^{11}$ As Rothbard says: "Kirzner's entrepreneur is a curious formulation. He need not, apparently, risk anything. He is a free-floating wraith, disembodied from real objects. He does not, and need not, possess any assets. All he need have to earn profits is a faculty of alertness to profit opportunities. Since he need not risk any capital assets to meet the chancy fate of uncertainty, he cannot suffer any losses. But if the Kirznerian entrepreneur owns no assets, then how in the world does he earn profits? Profits, after all, are simply the other side of the coin of an increase in the value of one's capital; losses are the reflection of a loss in capital assets. The speculator who expects a stock to rise uses money to purchase that stock; a rise or fall in the price of stock will raise or lower the value of the stock assets. If the price rises, the profits are one and the same thing as the increase in capital assets. The process is more complex but similar in the purchase or hiring of factors of production, the creating of a product and then its sale on the market. In what sense can an entrepreneur ever make profits if he owns no capital to make profits on?" (Rothbard, 1985, p. 282-83).
} 
Mises, by contrast, does not distinguish between "discovery" and "exploitation" phases of entrepreneurship. Rather, as noted above, he makes action the unit of analysis, with discovery and its antecedents implied by action. In our own approach, investment under uncertainty is both necessary and sufficient for entrepreneurship to take place. Investment, as human action, already implies purpose or objective, so that invoking opportunities and discovery is simply a relabeling. ${ }^{12}$ While Kirzner distinguishes sharply between "discovery" and "investment" or exploitation stages of the entrepreneurial process, he explicitly denies that the study of antecedents to discovery is part of the economic analysis of entrepreneurship. He maintains that his work "does not even aim to explore the roots and the determinants of individual entrepreneurial alertness" (Kirzner, 2009, p. 148).

Kirzner's objective, of course, is not to characterize entrepreneurship per se, but to explain the tendency for markets to clear. In the Kirznerian system, opportunities are (exogenous) arbitrage opportunities and nothing more. Entrepreneurship itself serves a purely instrumental function; it is the means by which Kirzner explains market clearing. As Kirzner (2009, p. 145) explains, reviewing his main contributions and critiquing his own critics: "my own work has nothing to say about the secrets of successful entrepreneurship. My work has explored, not the nature of the talents needed for entrepreneurial success, not any guidelines to be followed by would-be successful entrepreneurs, but, instead, the nature of the market process set in motion by the entrepreneurial decisions (both successful and unsuccessful ones!).”

\footnotetext{
${ }^{12}$ Salerno (1993, p.119) describes Mises's position this way: “[F]or Mises, the moment of choice coincides with the emergence of a value scale that is the raison d'être and consummation of the actor's previous 'discovery' activities and that provides the framework for purposive behavior. Choice and action can only be conceived as occurring within such a 'given situation.' Contrary to Kirzner's later interpretation of Mises, discovery cannot serve as the core of the central axiom in a praxeological system, precisely because there is no possibility of inferring from it the 'given situation' prerequisite to the moment of choice. A being who is ever seeking to 'discover changes that have occurred' in his situation can never act on those discoveries because he is incapable of creating the framework for choosing. In the newer Kirznerian interpretation, therefore, the Misesian homo agens has been transformed into homo quaerens, a perpetual and aimless seeker of new knowledge who is forever unable to turn it to account in improving his welfare; a shade who has become unstuck in (praxeological) time. ... [A]ccording to Mises, 'discovery' is logically implied in the very concept of choice and need not be posited as an independent facet of human purposiveness. . . Or, in other words, from the perspective of Misesian praxeology, entrepreneurial information gathering and forecasting are never autonomous and free-flowing activities directly expressing purposefulness, but are always rigidly governed by the exigencies of choosing under uncertainty."
} 
Of course, arbitrage opportunities cannot exist in a perfectly competitive general-equilibrium model, so Kirzner's framework assumes the presence of competitive imperfections. Beyond specifying general disequilibrium conditions, however, Kirzner offers no theory of how opportunities come to be identified, who identifies them, and so on; identification itself is a black box. The claim is simply that outside the Arrow-Debreu world in which all knowledge is effectively parameterized, opportunities for disequilibrium profit exist and tend to be discovered and exploited. In short, what Kirzner calls "entrepreneurial discovery" is simply that which causes markets to equilibrate. The focus is solely on the market process as being driven by alertness. Opportunity discovery is an analytical primitive, meaning that Kirzner does not address its antecedents/determinants.

In terms of levels of analysis, then, Kirzner's focus is entirely on abstract, aggregate effects of individual acts of alertness (i.e., a micro $\rightarrow$ macro relationship) It is conceivable that richer models of opportunity discovery, however-including those incorporating the cognitive and motivational antecedents that characterize the opportunity-discovery literature in management research — may yield additional insights in aggregate outcomes, relating for example to the speed of adjustment, possible path-dependencies and informational cascades in the adjustment process, the nature of coordinated states, etc. While such inquiries could be seen as natural extensions of some contributions to Austrian economics (particularly Hayek, 1937), they clearly go beyond the scope of Kirzner's interest and, perhaps, beyond his conception of what constitutes "pure theory."

However, Kirzner is ambiguous on these issues. First, he allows for error-correcting feedback effects from market interaction (i.e., a macro $\rightarrow$ micro relationship), not only from entrepreneurs who discover the profit opportunity introduced by other entrepreneurs' errors, but also from entrepreneurs recognizing their own earlier mistakes. It is not entirely clear whether such a learning capability is logically implied by the discovery notion. Moreover, Kirzner sometimes treats disequilibrium opportunities for profit as exogenous determinants of entrepreneurial activity. For example, he invokes an imagery of traffic lights (opportunities) that prompt behaviors (discovery) 
(Kirzner, 1992, p.151). On the other hand, he also treats opportunities metaphorically, noting that opportunities are "metaphorically waiting to be discovered," not literally waiting to be discovered Kirzner (1997). Kirzner's continued emphasis on the metaphorical nature of his constructs is somewhat puzzling. Arguing that a construct is a metaphor drives a wedge between the reality that the construct is supposed to throw light over and the construct itself. The construct and the reality it mirrors remain very different things (although illuminating the difference using the metaphor may be enlightening). In particular, use of metaphorical reasoning is different from using models, constructs, or ideal types meant to capture essential qualities of real phenomena (which a metaphor need not do). Perhaps Kirzner really means the latter, in which case the metaphor terminology appears misleading. Kirzner also insists that "the way in which policymakers understand the market economy is likely to carry enormously significant implications for encouragement or discouragement of entrepreneurial creativity" (Kirzner, 2009, p.151), suggesting that the models or ideal-typical notions of entrepreneurship held by policymakers affect entrepreneurial activity.

More generally, Kirzner clearly argues that government interference with the price mechanism, such as regulation, antitrust, and other government policies that affect business decision-making, inhibits the entrepreneurial discovery process (e.g., Kirzner, 1979b, 1985) through their impact on the "presence" of profit opportunities:

[D]irect controls by government on prices, quantities, or qualities of output production or input employment may unintentionally block activities which have, as yet, not been specifically envisaged by anyone. Where these blocked activities turn out to be entrepreneurially profitable activities (perhaps as a result of unforeseen changes in data), the likelihood of their being discovered is then sharply diminished. Without necessarily intending it, the spontaneous discovery process of the free market has thus been, to some extent, stifled or distorted (Kirzner, 1992). 
Thus, government intervention seems to be capable of influencing the sheer amount of entrepreneurial activity through its impact on "discoverable" opportunities (in this case blocking certain opportunities). It is of course also possible that government intervention may create new opportunities à la the opportunities for destructive rent-seeking discussed by Baumol (1994). Moreover, various indications of a direct effect from government intervention to discovery can also be found in Kirzner's work. For example, he argues that while "[w]e know very little that is systematic about what 'switches on' alertness . . . it does seem intuitively obvious that alertness can be 'switched off' by the conviction that external intervention will confiscate (wholly or in part) whatever one might notice" (Kirzner, 2009, p.151), Taxation hampers discovery by converting "open-ended" situations into "closed-ended" ones Kirzner (1985, p.111), while regulatory constraints "are likely to bar the discovery of pure profit opportunities" (Kirzner, 1985, p.142, emphasis in original). The suggestion is that government intervention, while not eliminating discovery entirely, reduces its quantity and quality. The argument strikes us as ad hoc, and inconsistent with the purely exogenous character of Kirznerian profit opportunities. Moreover, even if true, the welfare implications are ambiguous. When it comes to discovery, is "more" necessarily better?

\section{CONCLUSIONS}

Our goal here has been to point out some potential drawbacks of Kirzner's entrepreneurial discovery-process approach to the market. Outside the Austrian literature - and sometimes within it —one often gets the sense that Kirzner's framework is the Austrian approach to the study of prices and markets. In fact, however, there is tremendous variety within the contemporary Austrian school on such fundamental issues. Indeed, we think Kirzner's approach not only does not represent the logical continuation or extension of the basic Mengerian causal-realist approach, but instead departs from it in important ways.

We have focused here on Kirzner's portrayal of "pure entrepreneurship" and its role in the competitive market system. We have suggested that Kirzner goes too far in stripping the 
entrepreneurial ideal type of concrete content; the "entrepreneur" in his work is simply a coordination device, and that is all. This raises several problems. First, it presumes a certain model of the market in which "coordination," in the sense of converging to some kind of long-run, perfect-knowledge equilibrium, is the central problem economic theory needs to explain. Second, it limits the application of economics to real-world entrepreneurial behaviors and actions. We are not arguing that economists should embrace the much more expansive work on entrepreneurs undertaken in management research, describing them in various psychological dimensions and so on. Rather, we suggest that an emphasis on entrepreneurial action under uncertainty, focusing on investment, real prices, and the resulting profits and losses, provides richer insights into the market. 


\section{REFERENCES}

Baumol, W. J. 1994. Entrepreneurship, Management, and the Structure of Payoffs. Cambridge, MA: MIT Press.

Begley, Thomas M. and David P. Boyd. 1987. "Psychological Characteristics Associated with Performence in Entrepreneurial Firms and Smaller Businesses” Journal of Business Venturing, 2(1): 79-93.

Boettke, P. J. and D. L. Prychitko. 1994. The Market Process: Essays in Contemporary Austrian Economics. Northampton: Edward Elgar.

Buchanan, J. M. and V. J. Vanberg. 2008. "The Market as a Creative Process" Economics and philosophy, 7(02): 167-186.

Busenitz, L. W. 1996. ”Research on Entrepreneurial Alertness: Sampling, Measurement, and Theoretical Issues.” Journal of Small Business Management, 34(4).

Cantillon, R. 1755. Essai Sur La Nature De Commerce En Géneral. London: London: Macmillan.

Casson, M. 1982. The Entrepreneur: An Economic Theory. Lanham: Rowman \& Littlefield Pub Inc.

Casson, M. and N. Wadeson. 2007. "The Discovery of Opportunities: Extending the Economic Theory of the Entrepreneur" Small Business Economics, 28(4): 285-300. 
Companys, Y. E. and J. S. McMullen. 2007. "Strategic Entrepreneurs at Work: The Nature, Discovery, and Exploitation of Entrepreneurial Opportunities" Small Business Economics, 28(4): $301-322$

Cooper, Arnold C., Timothy B. Folta, and Carolyn Woo. 1995. ’Entrepreneurial Information Search” Journal of Business Venturing, 10(2): 107-120.

Demsetz, H. 1983. "The Neglect of the Entrepreneur." In Entrepreneurship, Joshua Ronen, ed ed.Anonymous , 271-280. Florence, MA: Free Press.

Fetter, F. A. 1907. The Principles of Economics. New York: “The” Century.

Foss, K., N. J. Foss, and P. G. Klein. 2007. ”Original and Derived Judgment: An Entrepreneurial Theory of Economic Organization” Organization Studies, 28(12): 1893.

Foss, K., N. J. Foss, P. G. Klein, and S. K. Klein. 2007. "The Entrepreneurial Organization of Heterogeneous Capital” Journal of Management Studies, 44(7): 1165.

Foss, N. J. and P. G. Klein. 2010. ’Entrepreneurial Alertness and Opportunity Discovery:

Origins, Attributes, Critique.” In The Historical Foundations of Entrepreneurship

ResearchAnonymous . Heatherley House: Edward Elgar Publishing Ltd.

Gaglio, C. M. and J. A. Katz. 2001. ’The Psychological Basis of Opportunity Identification: Entrepreneurial Alertness" Small Business Economics, 16(2): 95-111.

Hayek, F.A.v. 1937. "Economics and Knowledge," in F.A.v. Hayek. 1948. Individualism and Economic Order. Chicago: University of Chicago Press. 
High, J. 1982. "Alertness and Judgment: Comment on Kirzner," in I.M. Kirzner, ed. Method, Process, and Austrian Economics: Essays in Honor of Ludwig von Mises: 161-68.

Hood, J. N. and J. E. Young. 1993. ”Entrepreneurship's Requisite Areas of Development: A Survey of Top Executives in Successful Entrepreneurial Firms" Journal of Business Venturing, 8(2): 115-135.

Kaish, Stanley and Benjamin Gilad. 1991. "Characteristics of Opportunities Search of Entrepreneurs Versus Executives: Sources, Interests, General Alertness" Journal of Business Venturing, 6(1): 45-61.

Kirzner, I. M. 2009. "The Alert and Creative Entrepreneur: A Clarification" Small Business Economics, 32(2): 145-152.

------. 1978. Competition and Entrepreneurship. Chicago: University of Chicago Press. 1985. Discovery and the Capitalist Process. Chicago: University of Chicago Press.

-----. 1992. "Market Process Theory: In Defence of the Austrian Middle Ground." In The Meaning of the Market Process: Essays in the Development of Austrian EconomicsAnonymous , 3-37. Lexington: Lexington Press.

-----. 1992. The Meaning of Market Process. London: Routledge. 1999. "Mises and His Understanding of the Capitalist System" Cato Journal, 19(2): 215232. 
------. 1979. Perception, Opportunity, and Profit: Studies in the Theory of Entrepreneurship. Chicago: University of Chicago Press.

Kirzner, I.M. 1997. "Interview with Israel M. Kirzner" Austrian Economics Newsletter, 17(1).

Klein, P. G. 2008a. "The Mundane Economics of the Austrian School” Quarterly Journal of Austrian Economics, 11(3): 165-187.

-----. 2008b. "Opportunity Discovery, Entrepreneurial Action, and Economic Organization" Strategic Entrepreneurship Journal, 2(3): 175-190.

Knight, F. H. 1921. Risk, Uncertainty and Profit. Orlando: Houghton Mifflin Company.

Lachmann, L. M. 1986. The Market as an Economic Process. London: Blackwell Pub.

Lumpkin, G. T. and Gregory G. Dess. 1996. "Clarifying the Entrepreneurial Orientation

Construct and Linking it to Performance" The Academy of Management Review, 21(1): 135-172.

Machovec, F. M. 1995. Perfect Competition and the Transformation of Economics. New York: Routledge.

McMullen, J. S., L. A. Plummer, and Z. J. Acs. 2007. "What is an Entrepreneurial Opportunity?" Small Business Economics, 28(4): 273-283.

McMullen, J. S. and A. Shepherd. 2006. "Entrepreneurial Action and the Role of Uncertainty in the Theory of the Entrepreneur" Academy of Management Review, 31(1): 132. 
Mises, L. 1951. ”Profit and Loss.” In Planning for FreedomAnonymous . South Holland:

Libertarian Press.

Mises, L. and B. B. Greaves. 1949. Human Action: A Treatise on Economics. New Haven: Yale University Press.

Rothbard, M. N. 1985. ”Professor Hébert on Entrepreneurship” Journal of Libertarian Studies, 7(2): 281-286.

Salerno, J. T. 2008. ”The Entrepreneur: Real and Imagined” Quarterly Journal of Austrian Economics, 11(3): 188-207.

-----. 1993. "Mises and Hayek Dehomogenized" The Review of Austrian Economics, 6(2): 113146.

-----. 2002. "The Rebirth of Austrian economics —in Light of Austrian Economics" Quarterly Journal of Austrian Economics, 5(4): 111-128.

Schumpeter, J. A. 1911. The Theory of Economic Development: An Inquiry into Profits, Capital, Credit, Interest and the Business Cycle. Cambridge, MA: Harvard University Press.

Schutz, A. 1932. The Phenomenology of the Social World. Evanston: North-Western University Press.

Selgin, G.A. 1987. "Praxeology and Understanding" Review of Austrian Economics, 2: 19-58.

Shane, S. and S. Venkataraman. 2000. "The Promise of Entrepreneurship as a Field of Research" Academy of Management Review, 25: 217-226. 
Shane, S. A. 2003. A General Theory of Entrepreneurship: The Individual-Opportunity Nexus. Cheltenham: Edward Elgar Publications.

Short, J. C., D. J. Ketchen Jr, C. L. Shook, and R. D. Ireland. 2010. ”The Concept of “ Opportunity’ in Entrepreneurship Research: Past Accomplishments and Future Challenges” Journal of Management, 36(1): 40-65.

Vaughn, K. I. 1992. "The Problem of Order in Austrian Economics: Kirzner Vs. Lachmann" Review of Political Economy, 4(3): 251-274.

Venkataraman, S. 1997. ”The Distinctive Domain of Entrepreneurship Research: An Editor's Perspective" Advances in entrepreneurship, firm emergence, and growth, 3: 119-138.

Weber, M. 1997. The Methodology of the Social Sciences. New York: Free Press.

Williamson, O. E. 1996. The Mechanisms of Governance. Oxford: Oxford University Press.

Witt, Ulrich. 1998. 'Imagination and Leadership - the Neglected Dimension of an Evolutionary Theory of the Firm" Journal of Economic Behavior \& Organization. 


\section{SMG - Working Papers \\ www.cbs.dk/smg \\ 2003}

2003-1: Nicolai J. Foss, Kenneth Husted, Snejina Michailova, and Torben Pedersen: Governing Knowledge Processes: Theoretical Foundations and Research Opportunities.

2003-2: Yves Doz, Nicolai J. Foss, Stefanie Lenway, Marjorie Lyles, Silvia Massini, Thomas P. Murtha and Torben Pedersen: Future Frontiers in International Management Research: Innovation, Knowledge Creation, and Change in Multinational Companies.

2003-3: Snejina Michailova and Kate Hutchings: The Impact of In-Groups and OutGroups on Knowledge Sharing in Russia and China CKG Working Paper.

2003-4: Nicolai J. Foss and Torben Pedersen: The MNC as a Knowledge Structure: The Roles of Knowledge Sources and Organizational Instruments in MNC Knowledge Management CKG Working Paper.

2003-5: Kirsten Foss, Nicolai J. Foss and Xosé H. Vázquez-Vicente: “Tying the Manager's Hands": How Firms Can Make Credible Commitments That Make Opportunistic Managerial Intervention Less Likely CKG Working Paper.

2003-6: Marjorie Lyles, Torben Pedersen and Bent Petersen: Knowledge Gaps: The Case of Knowledge about Foreign Entry.

2003-7: Kirsten Foss and Nicolai J. Foss: The Limits to Designed Orders: Authority under "Distributed Knowledge" CKG Working Paper.

2003-8: Jens Gammelgaard and Torben Pedersen: Internal versus External Knowledge Sourcing of Subsidiaries - An Organizational Trade-Off.

2003-9: Kate Hutchings and Snejina Michailova: Facilitating Knowledge Sharing in Russian and Chinese Subsidiaries: The Importance of Groups and Personal Networks Accepted for publication in Journal of Knowledge Management.

2003-10: Volker Mahnke, Torben Pedersen and Markus Verzin: The Impact of Knowledge Management on MNC Subsidiary Performance: the Role of Absorptive Capacity CKG Working Paper.

2003-11: Tomas Hellström and Kenneth Husted: Mapping Knowledge and Intellectual Capital in Academic Environments: A Focus Group Study Accepted for publication in Journal of Intellectual Capital CKG Working Paper.

2003-12: Nicolai J Foss: Cognition and Motivation in the Theory of the Firm: Interaction or "Never the Twain Shall Meet"? Accepted for publication in Journal des Economistes et des Etudes Humaines CKG Working Paper.

2003-13: Dana Minbaeva and Snejina Michailova: Knowledge Transfer and Expatriation Practices in MNCs: The Role of Disseminative Capacity.

2003-14: Christian Vintergaard and Kenneth Husted: Enhancing Selective Capacity Through Venture Bases. 


\section{4}

2004-1: Nicolai J. Foss: Knowledge and Organization in the Theory of the Multinational Corporation: Some Foundational Issues

2004-2: Dana B. Minbaeva: HRM Practices and MNC Knowledge Transfer

2004-3: Bo Bernhard Nielsen and Snejina Michailova: Toward a Phase-Model of Global Knowledge Management Systems in Multinational Corporations

2004-4: Kirsten Foss \& Nicolai J Foss: The Next Step in the Evolution of the RBV: Integration with Transaction Cost Economics

2004-5: Teppo Felin \& Nicolai J. Foss: Methodological Individualism and the Organizational Capabilities Approach

2004-6: Jens Gammelgaard, Kenneth Husted, Snejina Michailova: Knowledge-sharing Behavior and Post-acquisition Integration Failure

2004-7: Jens Gammelgaard: Multinational Exploration of Acquired R\&D Activities

2004-8: Christoph Dörrenbächer \& Jens Gammelgaard: Subsidiary Upgrading? Strategic Inertia in the Development of German-owned Subsidiaries in Hungary

2004-9: Kirsten Foss \& Nicolai J. Foss: Resources and Transaction Costs: How the Economics of Property Rights Furthers the Resource-based View

2004-10: Jens Gammelgaard \& Thomas Ritter: The Knowledge Retrieval Matrix: Codification and Personification as Separate Strategies

2004-11: Nicolai J. Foss \& Peter G. Klein: Entrepreneurship and the Economic Theory of the Firm: Any Gains from Trade?

2004-12: Akshey Gupta \& Snejina Michailova: Knowledge Sharing in Knowledge-Intensive Firms: Opportunities and Limitations of Knowledge Codification

2004-13: Snejina Michailova \& Kate Hutchings: Knowledge Sharing and National Culture: A Comparison Between China and Russia

\section{5}

2005-1: Keld Laursen \& Ammon Salter: My Precious - The Role of Appropriability Strategies in Shaping Innovative Performance

2005-2: Nicolai J. Foss \& Peter G. Klein: The Theory of the Firm and Its Critics: A Stocktaking and Assessment

2005-3: Lars Bo Jeppesen \& Lars Frederiksen: Why Firm-Established User Communities Work for Innovation: The Personal Attributes of Innovative Users in the Case of Computer-Controlled Music

2005-4: Dana B. Minbaeva: Negative Impact of HRM Complementarity on Knowledge Transfer in MNCs

2005-5: Kirsten Foss, Nicolai J. Foss, Peter G. Klein \& Sandra K. Klein: Austrian Capital 
Theory and the Link Between Entrepreneurship and the Theory of the Firm

2005-1: Nicolai J. Foss: The Knowledge Governance Approach

2005-2: Torben J. Andersen: Capital Structure, Environmental Dynamism, Innovation Strategy, and Strategic Risk Management

2005-3: Torben J. Andersen: A Strategic Risk Management Framework for Multinational Enterprise

2005-4: Peter Holdt Christensen: Facilitating Knowledge Sharing: A Conceptual Framework

2005-5 Kirsten Foss \& Nicolai J. Foss: Hands Off! How Organizational Design Can Make Delegation Credible

2005-6 Marjorie A. Lyles, Torben Pedersen \& Bent Petersen: Closing the Knowledge Gap in Foreign Markets - A Learning Perspective

2005-7 Christian Geisler Asmussen, Torben Pedersen \& Bent Petersen: How do we Capture "Global Specialization" when Measuring Firms' Degree of internationalization?

2005-8 Kirsten Foss \& Nicolai J. Foss: Simon on Problem-Solving: Implications for New Organizational Forms

2005-9 Birgitte Grøgaard, Carmine Gioia \& Gabriel R.G. Benito: An Empirical Investigation of the Role of Industry Factors in the Internationalization Patterns of Firms

2005-10 Torben J. Andersen: The Performance and Risk Management Implications of Multinationality: An Industry Perspective

2005-11 Nicolai J. Foss: The Scientific Progress in Strategic Management: The case of the Resource-based view

2005-12 Koen H. Heimeriks: Alliance Capability as a Mediator Between Experience and Alliance Performance: An Empirical Investigation Into the Alliance Capability Development Process

2005-13 Koen H. Heimeriks, Geert Duysters \& Wim Vanhaverbeke: Developing Alliance Capabilities: An Empirical Study

2005-14 JC Spender: Management, Rational or Creative? A Knowledge-Based Discussion

\section{6}

2006-1: Nicolai J. Foss \& Peter G. Klein: The Emergence of the Modern Theory of the Firm

2006-2: Teppo Felin \& Nicolai J. Foss: Individuals and Organizations: Thoughts on a Micro-Foundations Project for Strategic Management and Organizational Analysis

2006-3: Volker Mahnke, Torben Pedersen \& Markus Venzin: Does Knowledge Sharing 
Pay? An MNC Subsidiary Perspective on Knowledge Outflows

2006-4: Torben Pedersen: Determining Factors of Subsidiary Development

2006-5 Ibuki Ishikawa: The Source of Competitive Advantage and Entrepreneurial Judgment in the RBV: Insights from the Austrian School Perspective

2006-6 Nicolai J. Foss \& Ibuki Ishikawa: Towards a Dynamic Resource-Based View: Insights from Austrian Capital and Entrepreneurship Theory

2006-7 Kirsten Foss \& Nicolai J. Foss: Entrepreneurship, Transaction Costs, and Resource Attributes

2006-8 Kirsten Foss, Nicolai J. Foss \& Peter G. Klein: Original and Derived Judgement: An Entrepreneurial Theory of Economic Organization

2006-9 Mia Reinholt: No More Polarization, Please! Towards a More Nuanced Perspective on Motivation in Organizations

2006-10 Angelika Lindstrand, Sara Melen \& Emilia Rovira: Turning social capital into business? A study of Swedish biotech firms' international expansion

2006-11 Christian Geisler Asmussen, Torben Pedersen \& Charles Dhanaraj: Evolution of Subsidiary Competences: Extending the Diamond Network Model

2006-12 John Holt, William R. Purcell, Sidney J. Gray \& Torben Pedersen: Decision Factors Influencing MNEs Regional Headquarters Location Selection Strategies

2006-13 Peter Maskell, Torben Pedersen, Bent Petersen \& Jens Dick-Nielsen: Learning Paths to Offshore Outsourcing - From Cost Reduction to Knowledge Seeking

2006-14 Christian Geisler Asmussen: Local, Regional or Global? Quantifying MNC Geographic Scope

2006-15 Christian Bjørnskov \& Nicolai J. Foss: Economic Freedom and Entrepreneurial Activity: Some Cross-Country Evidence

2006-16 Nicolai J. Foss \& Giampaolo Garzarelli: Institutions as Knowledge Capital: Ludwig M. Lachmann's Interpretative Institutionalism

2006-17 Koen H. Heimriks \& Jeffrey J. Reuer: How to Build Alliance Capabilities

2006-18 Nicolai J. Foss, Peter G. Klein, Yasemin Y. Kor \& Joseph T. Mahoney: Entrepreneurship, Subjectivism, and the Resource - Based View: Towards a New Synthesis

2006-19 Steven Globerman \& Bo B. Nielsen: Equity Versus Non-Equity International Strategic Alliances: The Role of Host Country Governance

\section{7}

2007-1 Peter Abell, Teppo Felin \& Nicolai J. Foss: Building Micro-Foundations for the Routines, Capabilities, and Performance Links 
2007-2 Michael W. Hansen, Torben Pedersen \& Bent Petersen: MNC Strategies and Linkage Effects in Developing Countries

2007-3 Niron Hashai, Christian G. Asmussen, Gabriel R.G. Benito \& Bent Petersen: Predicting the Diversity of Foreign Entry Modes

2007-4 Peter D. Ørberg Jensen \& Torben Pedersen: Whether and What to Offshore?

2007-5 Ram Mudambi \& Torben Pedersen: Agency Theory and Resource Dependency Theory: Complementary Explanations for Subsidiary Power in Multinational Corporations

2007-6 Nicolai J. Foss: Strategic Belief Management

2007-7 Nicolai J. Foss: Theory of Science Perspectives on Strategic Management Research: Debates and a Novel View

2007-8 Dana B. Minbaeva: HRM Practices and Knowledge Transfer in MNCs

2007-9 Nicolai J. Foss: Knowledge Governance in a Dynamic Global Context: The Center for Strategic Management and Globalization at the Copenhagen Business School

2007-10 Paola Gritti \& Nicolai J. Foss: Customer Satisfaction and Competencies: An Econometric Study of an Italian Bank

2007-11 Nicolai J. Foss \& Peter G. Klein: Organizational Governance

2007-12 Torben Juul Andersen \& Bo Bernhard Nielsen: The Effective Ambidextrous Organization: A Model of Integrative Strategy Making Processes.

\section{8}

2008-1 Kirsten Foss \& Nicolai J. Foss: Managerial Authority When Knowledge is Distributed: A Knowledge Governance Perspective

2008-2 Nicolai J. Foss: Human Capital and Transaction Cost Economics.

2008-3 Nicolai J. Foss \& Peter G. Klein: Entrepreneurship and Heterogeneous Capital.

2008-4 Nicolai J. Foss \& Peter G. Klein: The Need for an Entrepreneurial Theory of the Firm.

2008-5 Nicolai J. Foss \& Peter G. Klein: Entrepreneurship: From Opportunity Discovery to Judgment.

2008-6 Mie Harder: How do Rewards and Management Styles Influence the Motivation to Share Knowledge?

2008-7 Bent Petersen, Lawrence S. Welch \& Gabriel R.G. Benito: Managing the Internalisation Process - A Theoretical Perspective.

2008-8 Torben Juul Andersen: Multinational Performance and Risk Management Effects: Capital Structure Contingencies. 
2008-9 Bo Bernard Nielsen: Strategic Fit and the Role of Contractual and Procedural Governance in Alliances: A Dynamic Perspective.

2008-10 Line Gry Knudsen \& Bo Bernhard Nielsen: Collaborative Capability in R\&D Alliances: Exploring the Link between Organizational and Individual level Factors.

2008-11 Torben Juul Andersen \& Mahesh P. Joshi: Strategic Orientations of Internationalizing Firms: A Comparative Analysis of Firms Operating in Technology Intensive and Common Goods Industries.

2008-12 Dana Minbaeva: HRM Practices Affecting Extrinsic and Intrinsic Motivation of Knowledge Receivers and their Effect on Intra-MNC Knowledge Transfer.

2008-13 Steen E. Navrbjerg \& Dana Minbaeva: HRM and IR in Multinational Corporations: Uneasy Bedfellows?

2008-14 Kirsten Foss \& Nicolai J. Foss: Hayekian Knowledge Problems in Organizational Theory.

2008-15 Torben Juul Andersen: Multinational Performance Relationships and Industry Context.

2008-16 Larissa Rabbiosi: The Impact of Subsidiary Autonomy on MNE Knowledge Transfer: Resolving the Debate.

2008-17 Line Gry Knudsen \& Bo Bernhard Nielsen: Organizational and Individual Level Antecedents of Procedural Governance in Knowledge Sharing Alliances.

2008-18 Kirsten Foss \& Nicolai J. Foss: Understanding Opportunity Discovery and Sustainable Advantage: The Role of Transaction Costs and Property Rights.

2008-19 Teppo Felin \& Nicolai J. Foss: Social Reality, The Boundaries of Self-fulfilling Prophecy, and Economics.

2008-20 Yves Dos, Nicolai J. Foss \& José Santos: A Knowledge System Approach to the Multinational Company: Conceptual Grounding and Implications for Research

2008-21 Sabina Nielsen \& Bo Bernhard Nielsen: Why do Firms Employ foreigners on Their Top Management Teams? A Multi-Level Exploration of Individual and Firm Level Antecedents

2008-22 Nicolai J. Foss: Review of Anders Christian Hansen's “Uden for hovedstrømmen - Alternative strømninger i økonomisk teori"

2008-23 Nicolai J. Foss: Knowledge, Economic Organization, and Property Rights

2008-24 Sjoerd Beugelsdijk, Torben Pedersen \& Bent Petersen: Is There a Trend Towards Global Value Chain Specialization? - An Examination of Cross Border Sales of US Foreign Affiliates 
2008-25 Vikas Kumar, Torben Pedersen \& Alessandro Zattoni: The performance of business group firms during institutional transition: A longtitudinal study of Indian firms

2008-26 Sabina Nielsen \& Bo B. Nielsen: The effects of TMT and Board Nationality Diversity and Compensation on Firm Performance

2008-27 Bo B. Nielsen \& Sabina Nielsen: International Diversification Strategy and Firm Performance: A Multi-Level Analysis of Firm and Home Country Effects

\section{9}

2009-1 Nicolai J. Foss: Alternative Research Strategies in the Knowledge Movement: From Macro Bias to Micro-Foundations and Multi-Level Explanation

2009-2 Nicolai J. Foss \& Peter G. Klein: Entrepreneurial Alertness and Opportunity Discovery: Origins, Attributes, Critique

2009-3 Nicolai J. Foss \& Dana B. Minbaeva: Governing Knowledge: The Strategic Human Resource Management Dimension

2009-4 Nils Stieglitz \& Nicolai J. Foss: Opportunities and New Business Models: Transaction Cost and Property Rights Perspectives on Entrepreneurships

2009-5 Torben Pedersen: Vestas Wind Systems A/S: Exploiting Global R\&D Synergies

2009-6 Rajshree Agarwal, Jay B. Barney, Nicolai J. Foss \& Peter G. Klein: Heterogeneous Resources and the Financial Crisis: Implications of Strategic Management Theory

2009-7 Jasper J. Hotho: A Measure of Comparative Institutional Distance

2009-8 Bo B. Nielsen \& Sabina Nielsen: The Impact of Top Management Team Nationality Diversity and International Experience on Foreign Entry Mode

2009-9 Teppo Felin \& Nicolai Juul Foss: Experience and Repetition as Antecedents of Organizational Routines and Capabilities: A Critique of Behaviorist and Empiricist Approaches

2009-10 Henk W. Volberda, Nicolai J. Foss \& Marjorie E. Lyles: Absorbing the Concept of Absorptive Capacity: How To Realize Its Potential in the Organization Field

2009-11 Jan Stentoft Arlbjørn, Brian Vejrum Wæhrens, John Johansen \& Torben Pedersen: Produktion i Danmark eller offshoring/outsourcing: Ledelsesmæssige udfordringer 


\section{0}

2010-1 Dana B. Minbaeva, Kristiina Mäkelä \& Larissa Rabbiosi: Explaining Intraorganizational Knowledge Transfer at the Individual Level

2010-2 Dana B.Minbaeva \& Torben Pedersen: Governing Individual Knowledge Sharing Behavior

2010-3 Nicolai J. Foss \& Peter G. Klein: Alertness, Judgment, and the Antecedents of Entrepreneurship 